\title{
Perceived stress, psychological distress and serum anti-Müllerian hormone levels among infertile and fertile women in North-central Nigeria
}

Oyinkansola Islamiyat Lawal ${ }^{1 *}$ (D), Joshua Odunayo Akinyemi ${ }^{2}$ (D) Jameelu-deen Omokunmi Yusuff ${ }^{3}$ and Micheal Abiola Okunlola ${ }^{4}$

\begin{abstract}
Background: Previous studies reported that self-reported stress, stressful life events, and psychological distress influence ovarian ageing and response. However, there are limited, yet conflicting findings on the effect of stress and psychological distress on serum anti-Müllerian hormone (AMH) as a biomarker of ovarian reserve, response, and ageing. This case-control study aimed to determine if stress and psychological distress levels were associated with serum anti-Müllerian hormone levels among 81 infertile and 109 fertile women of reproductive age attending the gynaecology and immunization clinics of a tertiary hospital in North-central Nigeria, respectively. Stress and psychological distress were measured using the Perceived Stress scale-10 and Kessler Psychological Distress Scale10, respectively. The serum concentration of $\mathrm{AMH}$ was determined using enzyme-linked immunosorbent assays.

Results: There was a significantly higher stress $(p=0.001)$ and psychological distress $(p=0.005)$ levels among infertile women; however, there was no difference in serum anti-Müllerian hormone levels between the two groups $(p=0.409)$. There was no significant correlation found between perceived stress and serum anti-Müllerian hormone in both infertile $(r=0.041, p=0.719)$ and fertile $(r=-0.090, p=0.353)$ women. There was also no correlation between psychological distress and serum anti-Müllerian hormone in the infertile $(r=-0.020, p=0.860)$ and fertile $(r=-0.049, p=0.636)$ groups. Controlling for age and body mass index in multivariate linear regression; stress and psychological distress were not significantly associated with serum anti-Müllerian hormone $(B=-0.005 ; p=0.370$ and $B=-0.001 ; p=0.811$.

Conclusion: Self-reported stress and psychological distress are not associated with serum anti-Müllerian hormone levels in infertile and fertile women of reproductive age. Also, ovarian ageing was accelerated in infertile women when compared to fertile women; however, this does not appear to be related to stress or psychological distress. More research is needed to understand factors that may contribute to this accelerated decline.
\end{abstract}

Keywords: Infertility, Anti-Müllerian hormone, Stress, Psychological distress, Fertility

\footnotetext{
*Correspondence: islamiyatlawal2013@gmail.com; olawal0326@stu.ui.edu.ng

'Pan African University, Life and Earth Science Institute (including Health and Agriculture) (PAULESI), University of Ibadan, Ibadan, Nigeria

Full list of author information is available at the end of the article
}

\section{Springer Open}

(- The Author(s). 2020 Open Access This article is licensed under a Creative Commons Attribution 4.0 International License, which permits use, sharing, adaptation, distribution and reproduction in any medium or format, as long as you give appropriate credit to the original author(s) and the source, provide a link to the Creative Commons licence, and indicate if changes were made. The images or other third party material in this article are included in the article's Creative Commons licence, unless indicated otherwise in a credit line to the material. If material is not included in the article's Creative Commons licence and your intended use is not permitted by statutory regulation or exceeds the permitted use, you will need to obtain permission directly from the copyright holder. To view a copy of this licence, visit http://creativecommons.org/licenses/by/4.0/. 


\section{Background}

Infertility is a stressful condition for the couples involved [1]. Studies have shown that the state of being infertile and the medical interventions that follow cause social, biological, emotional, and economic distress in both men and women affected-with women bearing more of the burden [1-3]. These have also been shown to affect the overall outcome of fertility interventions [4-6].

The word stress and distress are often used interchangeably; although they are related concepts, they are different psychological occurrences. Stress is a state of physiological and psychological imbalance associated with an external (environmental or psychological) or internal conditions (illness or medical procedure) which are found to be taxing or threatening or exceed the coping capacity of an individual due to insufficient environmental or personal resources [7]. The stress process involves three components: (1) the stressor, (2) the perception of stress, and (3) the affective, behavioural, and/or biological response to stress (distress) [7]. Psychological distress, however, is a state of psychological or emotional suffering characterized by features of mental disorder especially depression and anxiety [8]. Psychological distress in some situations is an end product of the stress process $[8,9]$.

Evidence suggests that the experience of stress and distress (mainly anxiety and depression) contributes to reproductive failure [10]. Biological responses to stress may lead to elevated levels of stress hormones, which impairs granulosa cell function and compromise follicular maturation, resulting in the eventual reduction in the number of oocytes available for harvest in In-vitro fertilization (IVF) cycles [4, 11]. Researchers also reported that psychological stress had a positive association with antral follicular count (AFC) in younger women, while the age-related reduction in AFC was accelerated by increased stress levels in all age groups [12]. Also, the investigators reported that depressive symptomatology (positive and negative affect) moderates the effects of psychological stress on this decline [13]. These findings support the psychosocial acceleration theory, which suggests that stress increases reproductive readiness in the short term at the expense of accelerating ovarian ageing [12, 14].

Anti-Müllerian hormone (AMH) is a glycoprotein secreted by the granulosa cells of primary and secondary pre-antral and small antral follicles; it is believed to inhibit follicle-stimulating hormone (FSH)-dependent oocyte recruitment [15]. Therefore, it prevents premature recruitment of oocytes before maturation [15]. Available evidence indicates that serum AMH is a reliable marker of ovarian reserve (quantity and quality of oocytes), function, and response in ovarian stimulation protocols [15-17]. Previous studies suggest that it is lower among infertile women when compared to fertile women $[18,19]$.

A cross-sectional study demonstrated a negative correlation between salivary alpha-amylase-a biomarker of psychological stress-and serum AMH in Chinese women with unexplained infertility [20]. However, another cross-sectional study found no relationship between self-reported fertility-related stress and serum $\mathrm{AMH}$ in infertile women with unexplained infertility [21]. Contrary to these two, Kudesia et al. reported a positive correlation between self-reported chronic stress and serum AMH in premenopausal women [22].

There are limited, yet contradictory evidence on the effect of stress and psychological distress on serum $\mathrm{AMH}$, and available studies were mainly in developed nations outside of Africa. Therefore, this study aimed to determine if stress and psychological distress levels are related to serum AMH levels in infertile and fertile women attending the University of Ilorin Teaching Hospital, North-central Nigeria. We hypothesized that stress and psychological distress levels are associated with serum AMH in infertile and fertile women of reproductive age.

\section{Methods}

\section{Study design and participants}

This case-control study aimed to determine if stress and psychological distress are associated with serum AMH levels among 190 adult women of reproductive age: 81 infertile and 109 fertile women attending the gynaecology and immunization clinic of the University of Ilorin Teaching Hospital from March to July 2019. The power of this sample size was $91.52 \%$, using the means and standard deviations for serum AMH levels (infertile women $=1.60 \pm 2.51 \mathrm{ng} / \mathrm{ml}$ and fertile women $=2.71 \pm$ $1.91 \mathrm{ng} / \mathrm{ml}$ ) from the results of a study in Ile-Ife, Southwest of Nigeria [18].

We recruited study participants using purposive sampling following the study's inclusion and exclusion criteria. Study participants were adult women of reproductive age (18-45 years) with menstrual cycle length from 21 to 35 days. The infertile women were women attending the gynaecology clinic with 12-months history of inability to conceive despite adequate (2-3 times a week), unprotected sexual intercourse. The fertile controls were women attending the immunization clinic who had at least one pregnancy carried to term within the preceding 2 years, each pregnancy occurred spontaneously within 12 months of unprotected intercourse [18]. We excluded all women with a history of use of hormonal contraceptives or medications within 3 months before presentation, thyroid disorders, mental illness, use of chemotherapy and or radiotherapy, pelvic surger$y($ uterine or ovarian), and those who did not consent. 


\section{Data collection and analysis}

We determined stress and psychological distress levels using the self-administered perceived stress scale-10 and Kessler psychological distress scale-10, respectively. The perceived stress scale-10 is a 10-item questionnaire used to determine the level of self-reported stress in a population. It is the most widely used scale to determine the level of perceived stress in a population in the past month on a 5-point Likert scale (0-4). Positively worded questions are reverse scored, and scores range from 0 to 40. The higher the score, the higher the stress level [23]. The reliability coefficient (Cronbach's alpha) in this population was satisfactory at 0.72 for the scale.

Kessler psychological distress scale-10 is a 10 -item self-administered, short and simple measure of psychological distress. It measures anxiety and depressive symptoms that a person experienced in the past 4 weeks on a 5-point scale, and scores range from 10 to 50 . The higher the score, the higher the psychological distress level [24]. The reliability coefficient (Cronbach's alpha) in the study population was satisfactory at 0.84 .

We collected $3-5 \mathrm{ml}$ of a random peripheral venous blood sample from each participant by venipuncture after the skin was prepared with a spirit swab. Blood samples were collected in sterile plain sample bottles and transported to the laboratory in ice packs at $4{ }^{\circ} \mathrm{C}$. The sample was left to stand at room temperature for an hour, and after centrifuged for $10 \mathrm{~min}$ at $5000 \mathrm{rpm}$. Clear serum was pipetted into plain tubes in single-use aliquots and stored at $-20{ }^{\circ} \mathrm{C}$.

A consultant chemical pathologist analysed serum AMH concentration using human AMH enzyme-linked immunosorbent assay (ELISA) following the manufacturer's manual (Calbiotech Inc. El Cajon, CA, USA; 2018) at the chemical pathology research laboratory of the University of Ilorin Teaching Hospital. The sensitivity of the test was $0.039 \mathrm{ng} / \mathrm{ml}$.

Independent variables were age, body mass index (BMI), psychological distress, and stress while the dependent variable was serum AMH. We conducted data analysis using SPSS version 25 for Windows (IBM Corp., Armonk, NY, USA, version 25.0). Normally distributed continuous variables were expressed in means \pm standard deviation, and those not normally distributed were summarized as medians (interquartile range); furthermore, independent sample $t$ test and Mann-Whitney $U$ test were used as tests of difference, respectively. Categorical data were expressed in frequencies and percentages. Serum AMH was $\log _{10}$-transformed to meet the requirements for linear regression analysis. Tests of relationships between study variables were analysed using the Spearman correlation and linear regression. The level of significance was set at $5 \%$.

\section{Results}

Table 1 summarizes the study variables by fertility status. There was a significant difference in age, body mass index (BMI), stress, and psychological distress between infertile and fertile women in this study. However, there was no difference in serum AMH levels between the two groups.

Among the infertile women, 37\% had primary infertility while $63 \%$ had secondary infertility, with an average duration of infertility of $3.93 \pm 2.36$ years. The distribution of clinical diagnosis among the infertile women was: $40.7 \%$ unexplained infertility, $16 \%$ anovulation (including PCOS), and tubal factors respectively, $6.2 \%$ male-factor, $8.6 \%$ uterine factors and $12.5 \%$ more than one diagnosis.

There was a significant negative relationship between age and serum anti-Müllerian hormone level in infertile $(B=-0.042 ; p=0.000)$ and fertile $(B=-0.026 ; p=$ 0.002 ) women (Figs. 1 and 2). However, linear regression showed a positive relationship with BMI in both groups, but this was only significant in the infertile women $(B=$ 0.021; $p=0009$ ) (Figs. 3 and 4).

There was no significant correlation between stress and serum AMH levels among infertile and fertile women. Also, correlation analysis showed no significant relationship between psychological distress and serum $\mathrm{AMH}$ in infertile and fertile women (Table 2).

Furthermore, in Tables 3 and 4, multivariate analysis controlling for age and BMI showed no significant relationship between stress and AMH level as well as psychological distress and serum AMH levels. However, the significant influence of age on serum AMH remained constant in both groups; although, an additional reduction of $0.1 \%$ in serum AMH with a year increase in age was noted among the fertile group $(B=-0.027 ; p=$ 0.002 ). BMI was only a predictor of serum AMH in infertile women, with a $0.1 \%$ decrease in the positive effect on serum AMH levels after adjusting for age, stress, and psychological distress.

Following the exclusion of women with polycystic ovarian syndrome (PCOS) in the infertile group, multivariate linear regression analysis demonstrated persistence in the significant negative relationship of $\mathrm{AMH}$ with age $(B=-0.035 ; p=0.000)$, while the relationship between AMH and BMI $(B=0.015 ; p=0.099)$ in infertile women $(n=74)$ became statistically insignificant. Stress $(B=0.000 ; p=0.987)$ and psychological distress $(B=-0.001 ; p=0.934)$ had no significant relationship with serum AMH.

Multivariate analysis demonstrated no significant difference in serum AMH levels between the infertile and fertile women $(B=0.043 ; p=0.409)$ after controlling for age, BMI, stress, psychological distress, and excluding infertile women with PCOS. 
Table 1 Summary of study variables among infertile and fertile women

\begin{tabular}{llll}
\hline Variables & $\begin{array}{l}\text { Infertile } \\
\text { mean } \pm \text { S.D/median (IQR) }\end{array}$ & $\begin{array}{l}\text { Fertile } \\
\text { mean } \pm \text { S.D/median(IQR) }\end{array}$ & $\begin{array}{l}\boldsymbol{p} \text { value } \\
\boldsymbol{t} \text { test/Mann-Whitney } \boldsymbol{U}\end{array}$ \\
\hline Age (years) & $31.6 \pm 4.5$ & $29.9 \pm 3.9$ & $0.005^{*}$ \\
BMI $\left(\mathbf{k g} / \mathbf{m}^{2}\right)$ & $25.4(5.88)$ & $23.8(6.50)$ & $0.007^{*}$ \\
Stress & $18.10 \pm 4.95$ & $15.53 \pm 5.35$ & $0.001^{*}$ \\
Psychological distress & $21(10)$ & $19(8)$ & $0.005^{*}$ \\
Serum AMH $\mathbf{( n g / m l )}$ & $5.50(9.90)$ & $5.59(9.20)$ & 0.494 \\
\hline
\end{tabular}

*Statistical significance at $5 \%$ level of significance

\section{Discussion}

We found that infertile women reported significantly higher stress and psychological distress levels than fertile women, similar to findings from previous studies $[1,3]$. This confirms that infertility is associated with high psychosocial strain and infertile women experience higher levels of stress and psychological distress compared to fertile women.

However, we found no significant difference in serum $\mathrm{AMH}$ levels between the two groups, which is contrary to previous studies comparing serum AMH among infertile and fertile women, in which authors reported a significantly lower serum AMH level among infertile women $[18,19]$. The contradiction between our findings and that of other studies may be due to the inclusion of women with polycystic ovary syndrome (PCOS) - which is associated with significantly higher levels of serum AMH - in our study, contrary to previous studies.
However, we found no significant difference in serum AMH levels between the two groups after the exclusion of women with PCOS from the infertile group and controlling for age, BMI, stress, and psychological distress. Furthermore, given the heterogeneous nature of infertility, a measure of ovarian function is not an exclusive marker of fertility. Therefore, findings may vary based on underlying factors responsible for infertility in the women in each study population.

Also, we found no significant correlation between stress and serum AMH level among infertile and fertile women. This is similar to findings by Vitek et al. in which psychosocial stress was not demonstrated to have any relationship with AFC or AMH among women with unexplained infertility [21]. Conversely, Dong et al. found a significant negative correlation between salivary amylase as a marker of psychological stress and serum $\mathrm{AMH}$ among Chinese women with unexplained

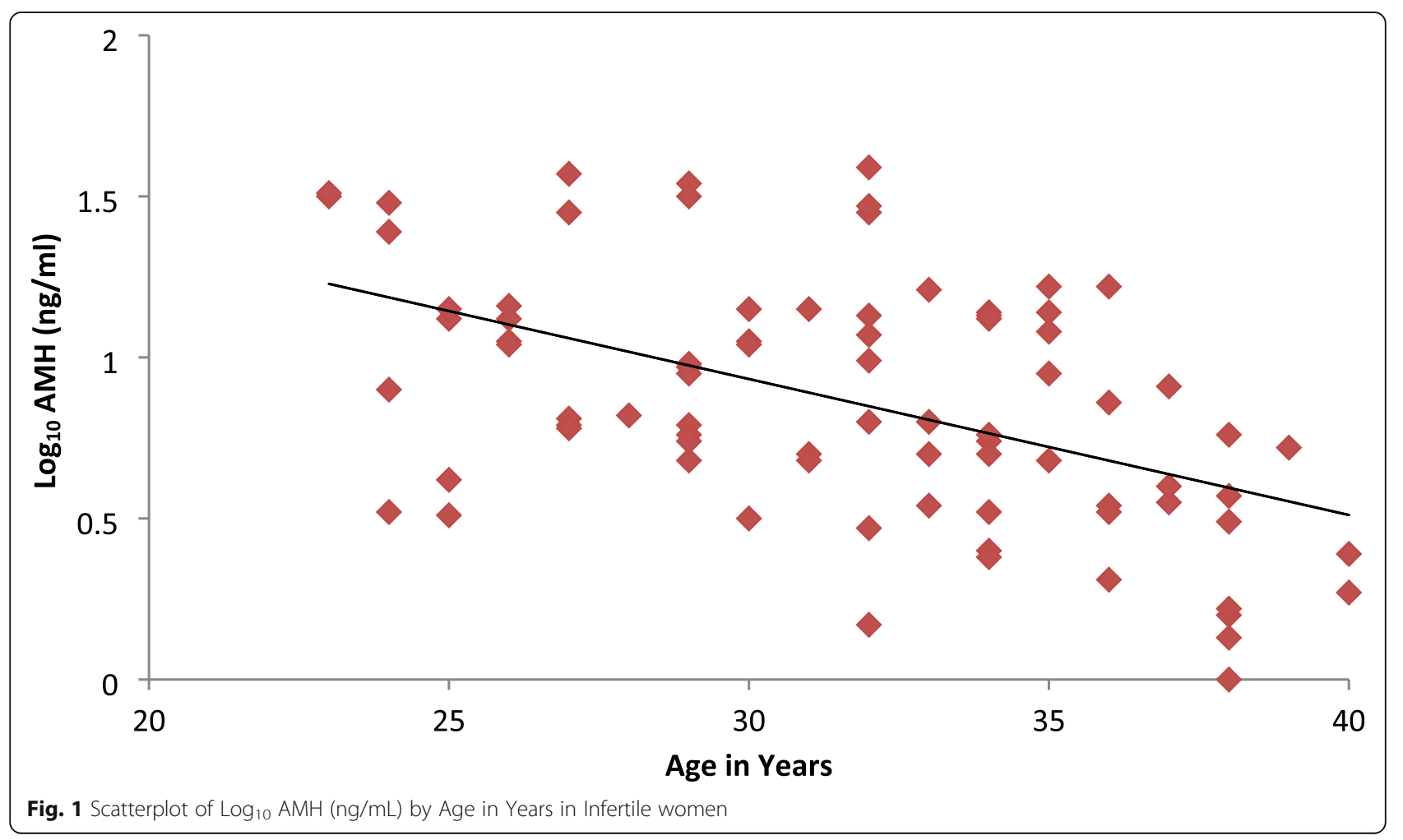



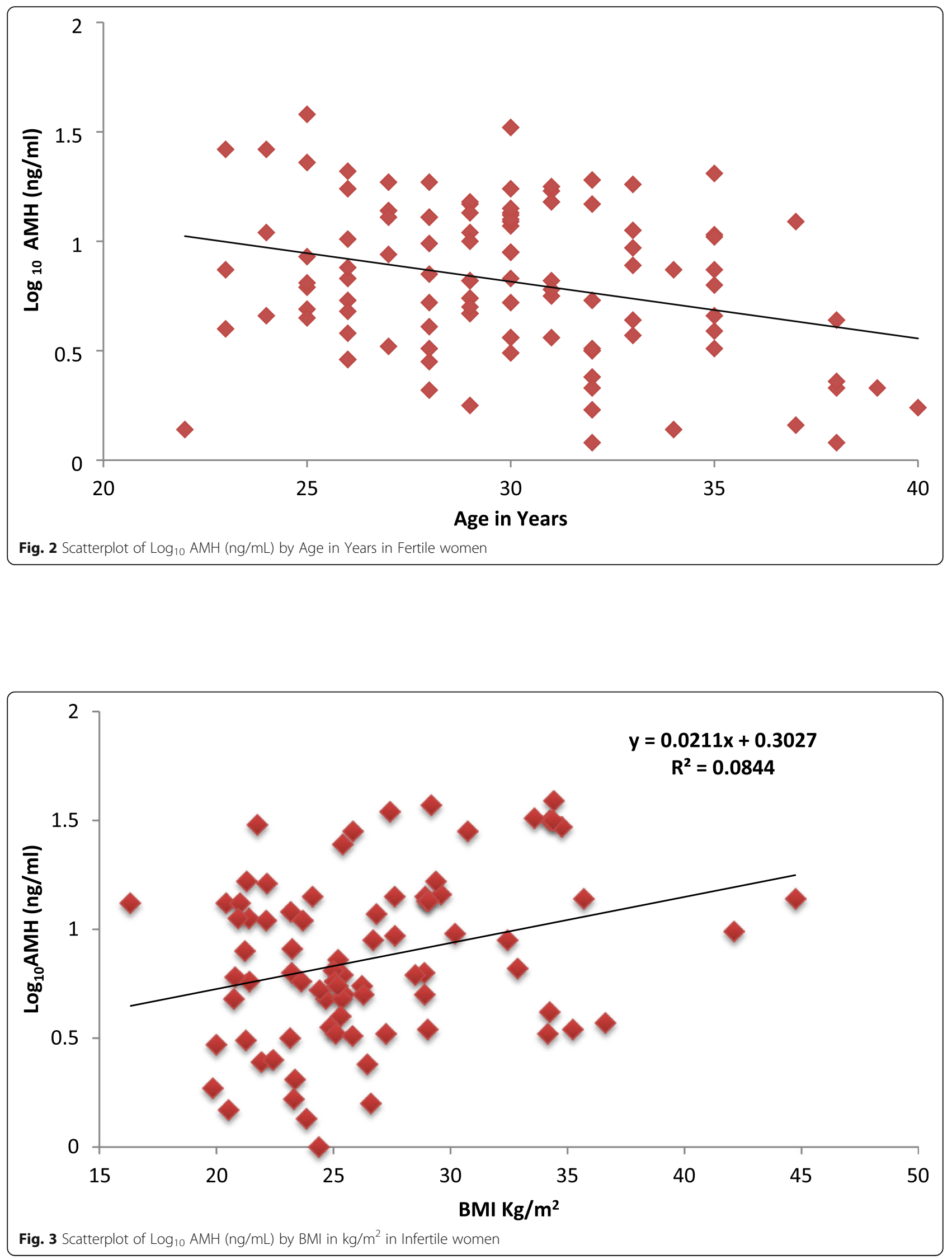


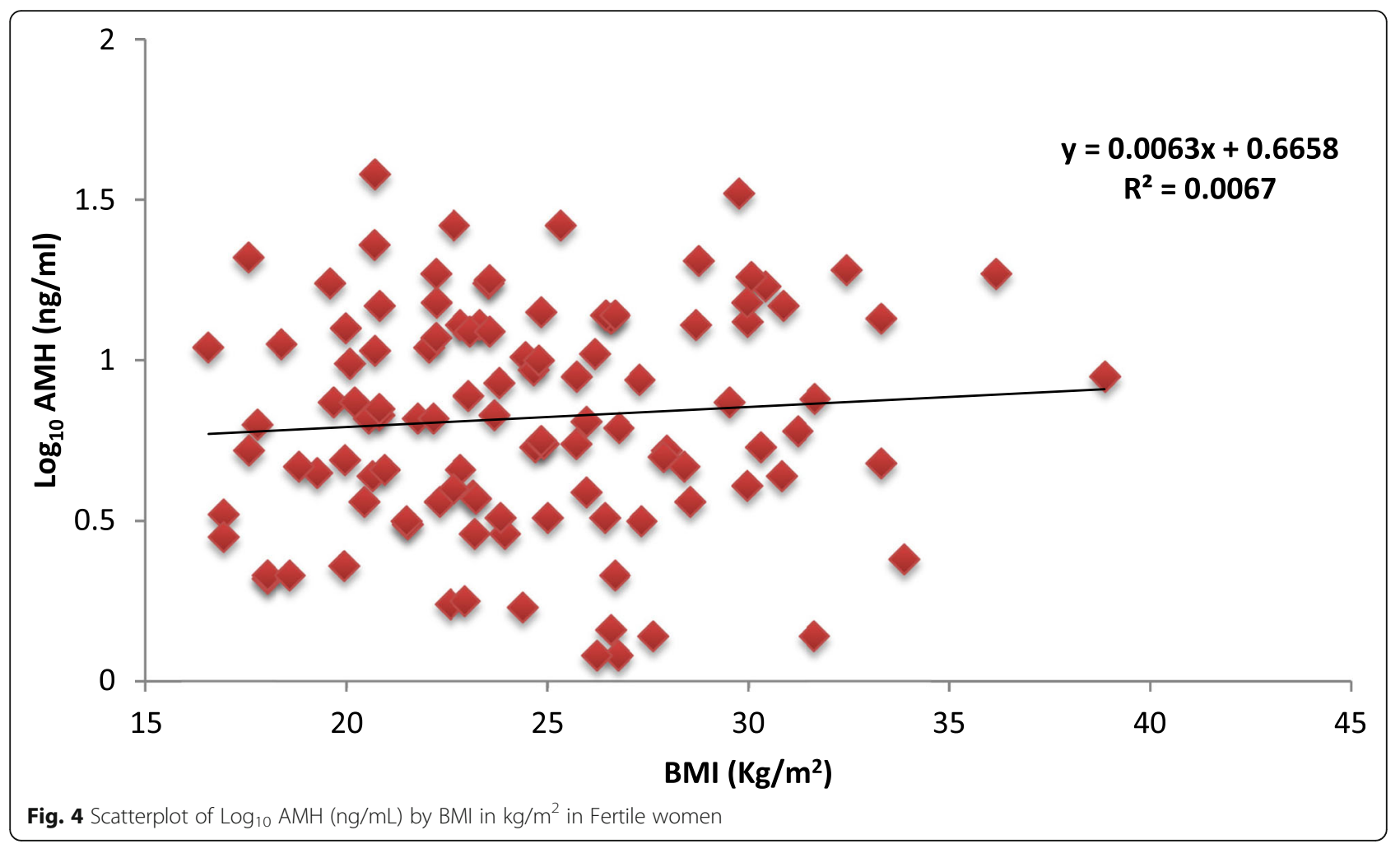

infertility [20]. Contrary to previous findings, Kudesia et al. reported a positive correlation between chronic stress-measured with Wheaton's Chronic Stress Scaleand serum AMH in pre-menopausal women [22].

The contradictions could be because of the difference in the marker of psychological stress used and the overall sensitivity of perceived stress scale-10 used in our study to the biological response to stress. Since some of the theories surrounding the influence of psychological stress borders on the eventual influence the biological response to stress can have on human reproduction [11], a biomarker of this process will most likely be a more sensitive measure of an effect. Although perceived stress scale is a valid and reliable measure of stress [24, 25], it may not translate in all situations to the biological response or vulnerability to stress which could influence a significant change in serum AMH levels in these women.

We found no significant correlation between psychological distress-measured by the Kessler psychological distress scale-10-and serum AMH in infertile and fertile women. This finding is similar to those of Vitek et al. in which psychological distress-measured by the Patient Health Questionnaire (PHQ) - did not demonstrate any significant relationship with serum AMH or AFC [21]. Perhaps, the nonspecific and subjective nature of the instruments used affects their sensitivity to the biological distress that affects serum AMH levels.

We found that with an increase in age, there was a corresponding reduction in serum AMH among infertile and fertile women. This is similar to findings by other studies and lends credence to the use of serum AMH as a marker of ovarian ageing $[26,27]$. However, infertile women showed almost twice the reduction in serum AMH with age, when compared to fertile women in this study population, suggesting that ovarian ageing is accelerated in women with infertility. Contrary to findings from previous studies, the rate of decrease in serum $\mathrm{AMH}$ with age remained constant in both groups despite controlling for stress and psychological distress,

Table 2 Correlation between stress, psychological distress, and AMH among infertile and fertile women

\begin{tabular}{lllll}
\hline & Infertile & & \multicolumn{2}{l}{ Fertile } \\
\cline { 2 - 3 } Variables & Spearman's correlation $(\boldsymbol{r})$ & $\boldsymbol{p}$ & & Spearman's correlation $(\boldsymbol{r})$ \\
\hline Stress level & 0.041 & 0.719 & -0.090 & $\boldsymbol{p}$ \\
Psychological distress level & -0.020 & 0.860 & -0.049 & 0.353 \\
\hline
\end{tabular}


Table 3 Multivariate linear regression among infertile women

\begin{tabular}{|c|c|c|c|c|c|}
\hline \multirow[t]{2}{*}{ Model: $\log _{10}$ AMH } & \multirow[b]{2}{*}{$B$} & \multirow[b]{2}{*}{ Std. error } & \multirow[t]{2}{*}{$\boldsymbol{p}$ value } & \multicolumn{2}{|c|}{ 95.0\% confidence interval for $\boldsymbol{B}$} \\
\hline & & & & Lower limit & Upper limit \\
\hline (Constant) & 1.667 & 0.378 & 0.000 & 0.915 & 2.418 \\
\hline Stress & -0.002 & 0.009 & 0.852 & -0.020 & 0.016 \\
\hline Psychological distress & 0.001 & 0.009 & 0.914 & -0.012 & 0.013 \\
\hline Age (years) & -0.042 & 0.008 & $0.000^{*}$ & -0.058 & -0.026 \\
\hline Body mass index $\left(\mathrm{kg} / \mathrm{m}^{2}\right)$ & 0.020 & 0.007 & $0.005^{*}$ & -0.006 & 0.034 \\
\hline
\end{tabular}

*Statistical significance at $5 \%$ level of significance

which suggests that the acceleration in ovarian ageing in infertile women was not dependent on these psychological variables $[12,13]$. However, the rate of reduction in serum AMH with age was $0.7 \%$ less following the exclusion of women with PCOS from the infertile group. This suggests that the inclusion of young women with PCOS with higher serum AMH levels contributed partly to the accelerated decrease in serum AMH with age in the infertile group. Also, previous studies reported that women with PCOS have an accelerated decrease in serum AMH with age compared to non-PCOS controls $[28,29]$.

There was a positive relationship between BMI and $\mathrm{AMH}$ in the infertile group, while none was found in the fertile group. This contradicts the findings by previous studies in southwest Nigeria, in which Okunola et al. found no relationship between BMI and random serum $\mathrm{AMH}$ in infertile and fertile women, while Oke and colleagues reported no significant relationship between $\mathrm{BMI}$ and day $3 \mathrm{AMH}$ in all study participants $[18,30]$. Outside Nigeria, Freeman et al. reported a negative relationship between BMI and serum AMH in Caucasians and African-American women of late reproductive age, while Moy et al. in a multi-ethnic study among infertile women also found a negative correlation between BMI and serum AMH levels in Caucasians, although no relationship was demonstrated in African-American, Hispanic, or Asian women [31, 32]. Dólleman et al., however, demonstrated no relationship between levels of BMI and serum AMH in a large population study of premenopausal women [33].
However, following the exclusion of women with PCOS in the infertile group, we found no significant relationship between BMI and serum $\mathrm{AMH}$, suggesting that the significant positive relationship demonstrated in the infertile group was due to the inclusion of anovulatory women with PCOS in the infertile group of this study, which is often associated with high BMI and high serum AMH levels [34].

\section{Strength and limitations}

The case-control design of our study gave room for comparison and sub-analysis to further understand the effect of stress and psychological distress on serum AMH levels in infertile and fertile women, independently. This further removed the influence of infertility as a confounder, since stress, psychological distress, and abnormalities of serum AMH have all been found to be independently associated with infertility.

However, this study is not without its limitations. In determining the effect of stress and psychological distress on serum AMH, self-administered scales-which measured the perception of stress and psychological distress over a month-used are highly subjective and could be biased by the language barrier, concentration, and environment of the participants during the process of completing the questionnaires, although there is evidence that perceived-stress scale scores correlate with the biological response to stress [25]. The inclusion of a more objective measure of the biological response and vulnerability to stress would have increased the

Table 4 Multivariate linear regression among fertile women

\begin{tabular}{llllll}
\hline Model: $\log _{\mathbf{1 0}} \mathrm{AMH}$ & $\boldsymbol{B}$ & $\boldsymbol{p}$ value & \multicolumn{2}{l}{$95.0 \%$ confidence interval for $\boldsymbol{B}$} \\
\cline { 5 - 6 } & $\boldsymbol{B}$ & Std. error & & Lower limit & 0.937 \\
(Constant) & 1.561 & 0.315 & 0.000 & -0.020 & 0.008 \\
Stress & -0.006 & 0.007 & 0.409 & -0.013 & 0.008 \\
Psychological distress & -0.003 & 0.005 & 0.625 & -0.043 & -0.011 \\
Age (years) & -0.027 & 0.008 & $0.002^{*}$ & -0.006 & 0.023 \\
Body mass index $\left(\mathbf{k g} / \mathbf{m}^{\mathbf{2}}\right)$ & 0.008 & 0.007 & 0.250 & &
\end{tabular}

*Statistical significance at $5 \%$ level of significance 
reliability of stress measurement and broadened the scope of the study.

\section{Conclusion}

The results of our study suggest that self-reported stress and psychological distress has no effect on serum $\mathrm{AMH}$ levels in infertile and fertile women within the reproductive age in North-central Nigeria. Serum AMH level is not exclusively a reliable marker of fertility; since the underlying pathology surrounding infertility in women are diverse and heterogeneous. Furthermore, age-related decline in serum $\mathrm{AMH}$ is accelerated in women with infertility; however, from our findings, this is not stressrelated. Therefore, more research is required to determine factors that may influence this accelerated decline in infertile women as opposed to fertile women.

\section{Abbreviations}

AFC: Antral follicular count; AMH: Anti-Müllerian hormone; BMl: Body mass index; ELISA: Enzyme-linked immunosorbent assay; IQR: Interquartile range; PCOS: Polycystic ovary syndrome; PHQ: Patient health questionnaire; SD: Standard deviation

\section{Acknowledgements}

We express our sincere gratitude to the Pan African University, an initiative of the African Union Commission for the provision of funds for running this research. Also, appreciation goes to the University of Ilorin Teaching Hospital for the provision of support and facility for the running of this study. We also appreciate Dr Sikiru A. Biliaminu, Consultant Chemical Pathologist, University of Ilorin Teaching hospital, for his contribution towards the hormonal analysis for this study, and Dr Imran O. Morhason-Bello and Dr Jubril O. Abdulmalik of the Department of Obstetrics and Gynaecology and Department of Psychiatry, University College Hospital, for their scholarly inputs towards the research.

\section{Authors' contributions}

O.I was involved in the study design, literature search, data collection, input and analysis, laboratory analysis, manuscript drafting, and review. J.O was involved in the study design, result interpretation, and manuscript review. J.O.Y contributed to the laboratory analysis, interpretation of results, and manuscript review. M.O was involved in the manuscript editing and review. The manuscript was read and approved by all authors for submission.

\section{Funding}

African Union through the Pan African University Scholarship

\section{Availability of data and materials}

Data supporting findings are available from the corresponding author on reasonable request.

\section{Ethics approval and consent to participate}

This was gotten from the University of llorin institutional ethics review committee (ERC/PAN/2019/01/1869) in February 2019. Informed consent was signed by each participant before participation.

\section{Consent for publication}

Not applicable

\section{Competing interests}

The authors have no competing interest to declare.

\section{Author details}

${ }^{1}$ Pan African University, Life and Earth Science Institute (including Health and Agriculture) (PAULESI), University of Ibadan, Ibadan, Nigeria. ${ }^{2}$ Department of Epidemiology and Medical Statistics, College of Medicine, University of Ibadan, Ibadan, Nigeria. ${ }^{3}$ Department of Chemical Pathology and
Immunology, University of Ilorin Teaching Hospital, Ilorin, Nigeria. ${ }^{4}$ Department of Obstetrics and Gynaecology, College of Medicine, University of Ibadan, Ibadan, Nigeria.

Received: 31 January 2020 Accepted: 19 May 2020

Published online: 09 June 2020

\section{References}

1. Chehreh R, Ozgoli G, Abolmaali K, Nasiri M, Mazaheri E (2019) Comparison of the infertility-related stress among couples and its relationship with infertility factors. Int J Women's Heal Reprod Sci 7(3):313-318 https://doi. org/10.15296/ijwhr.2019.52

2. Prasad S, Kumar Y, Nayar P, Prasad S, Sharma G (2017) A prospective study to assess the mental health and quality of life in women undergoing assisted reproduction. Fertil Sci Res 4(2):117-125

3. Yusuf L. Depression, anxiety and stress among female patients of infertility; a case-control study (2016). Pak J Med Sci. 32(6):1340-1343. doi.org/10.1266 9/pjms.326.10828

4. Boivin J, Schmidt L (2005). Infertility-related stress in men and women predicts treatment outcome 1 year later. Fertil Steril 83(6):1745-52. doi.org/1 0.1016/j.fertnstert.2004.12.039

5. Qu F, Wu Y, Zhu Y, Barry J, Ding T, Baio G, et al (2017). The association between psychological stress and miscarriage: a systematic review and meta-analysis. Sci Rep 7:1-8. doi.org/10.1038/s41598-017-01792-3.

6. Purewal S, Chapman SCE, van den Akker OBA (2017) A systematic review and meta-analysis of psychological predictors of successful assisted reproductive technologies. BMC Res Notes 2017;10(1):711. doi.org/10.1186/ s13104-017-3049-z.

7. Cohen, S., Kessler, R.C, Gordon, L.U (1995) Measuring stress: a guide for health and social scientists. Oxford Univ. Press; New York

8. Drapeau A, Marchand A, Beaulieu-Prevost D (2012) Epidemiology of psychological distress. In: Mental illnesses - understanding, prediction and control. IntechOpen; Rijeka 105-34. doi.org/10.5772/30872

9. Mirowsky, J., and. Ross, C.E (2002) Selecting outcomes for the sociology of mental health: issues of measurement and dimensionality. Journal of Health and Social Behavior 43:152-170

10. Rooney KL, Domar AD (2018) The relationship between stress and infertility. Dialogues Clin Neurosci 20(1):41-47

11. Ebbesen SMS, Zachariae R, Mehlsen MY, Thomsen D, Højgaard A, Ottosen L et al (2018) Stressful life events are associated with a poor in-vitro fertilization ( IVF ) outcome: a prospective study. Hum Reprod 24(9):2173-2182

12. Bleil ME, Adler NE, Pasch LA, Sternfeld B, Gregorich SE, Rosen MP et al (2012) Psychological stress and reproductive aging among pre-menopausal women. Hum Reprod 27(9):2720-2728

13. Bleil ME, Adler NE, Pasch LA, Sternfeld B, Gregorich SE, Rosen MP et al (2013) Depressive symptomatology, psychological stress, and ovarian reserve: a role for psychological factors in ovarian aging? Menopause 19(11): $1176-1185$

14. Ellis BJ (2004) Timing of pubertal maturation in girls: an integrated life history approach. Psychol Bull 130:920-958

15. Durlinger AL, Visser JA, Themmen AP (2002) Regulation of ovarian function: the role of anti-Müllerian hormone. Reproduction 124:601-9. doi.org/10.153 0/rep.0.1240601

16. Iwase A, Nakamura T, Osuka S, Takikawa S (2016) Anti-Müllerian hormone as a marker of ovarian reserve: what have we learned, and what should we know? Reprod Med Biol 15:127-136

17. Seifer DB, David T. MacLaughlin P. B, Feng B, Shelden RM, Johnson RW (2002) Early follicular serum Mullerian substance levels are associated with ovarian response during assisted reproductive technology cycles. Fertil Steril 77(3):7-10.

18. Okunola T, Ajenifuja KO, Loto OM, Salawu A, Omitinde OS (2017) Follicle stimulating hormone and anti-Müllerian hormone among fertile and infertile women in Ile-Ife, Nigeria: is there a difference? Int J Fertil Steril 11(1):33-39.

19. Kalaiselvi VS, Saikumar P, Prabhu K, Prashanth Krishna G (2012) The antiMullerian hormone-a novel marker for assessing the ovarian reserve in women with regular menstrual cycles. J Clin Diagnostic Res 6(10):1636-1639

20. Dong Y, Zhou F, Sun Y (2017) Psychological stress is related to a decrease of serum anti-müllerian hormone level in infertile women. Reprod Biol Endocrinol 15(51):1-4. doi.org/10.1186/s12958-017-0271-4 
21. Vitek W, Barrett ES, Hoeger K, Diamond MP, Cedars M, Steiner AZ (2016) Psychological stress and ovarian reserve among women with unexplained infertility. Fertil Steril. 106(3):e66

22. Kudesia R, Lipton RB, Neal-Perry GS (2018) Impact of stress on ovarian reserve and function. Fertil Steril 110(4): e149 - e150. doi.org/10.1016/j. fertnstert.2018.07.442.

23. Cohen S, Kamarck T, Mermelstein R (1983) A global measure of perceived stress. Journal of Health and Social Behavior 24(4):385-396. https://doi.org/ $10.2307 / 2136404$

24. Kessler RC, Andrews G, Colpe L, Hiripi E, Mroczek DK, Normand S-LT et al (2002) Short screening scales to monitor population prevalence and trends in non-specific psychological distress. Psychol Med 32(6):959-976

25. Han AA, Vrana JA, Mitchell C, Boyd W (2015) Identification of biomarkers related to perceived stress scale-10 and the evaluation of the survey components. J Med Genomics Biomar 2(1):003

26. Okunola OT, Ajenifuja OK, Loto MO, Salawu A, Omitinde OS, Akande J et a (2016) Age-specific nomograms for follicle-stimulating hormone and antiMullerian hormone: A pilot study in lle-lfe, Nigeria. Int J Reprod BioMed 14(12):777-782

27. Wiweko B, Mustikaning D, Prawesti P (2013) Chronological age vs biological age: an age-related normogram for antral follicle count, FSH and antiMullerian hormone. J Assist Reprod Genet 30:1563-1567. https://doi.org/10. 1007/s10815-013-0083-1

28. Roca FJ, Schutt AK, Mazur EC, Gibbons WE, Kovanci E, Schutt AK et al (2012) Women with polycystic ovary syndrome experience more rapid decline in anti-müllerian hormone levels. Fertil Steril 98(3):S116 https://doi.org/10.1016/ j.fertnstert.2012.07.429

29. Ahmad AK, Kao C, Quinn M, Lenhart N (2018) Differential rate in decline in ovarian reserve markers in women with polycystic ovary syndrome compared with control subjects: results of a longitudinal study. Fertil Steril 109(3):526-531 https://doi.org/10.1016/j.fertnstert.2017.11.012

30. Oke EO, Oke OF, Afolabi A, Akande JO, Oloyede WT, Kareem A et al (2019) Comparison of serum level of anti-Müllerian hormone in fertile and infertile women in South West Nigeria. International Journal of medicine in developing countries 3(1):43-49 https://doi.org/10.24911/JJMDC.511542882156

31. Freeman EW, Gracia CR, Sammel MD, Lin H, Lim LCL, Strauss JF (2007) Association of anti-müllerian hormone levels with obesity in late reproductive-age women. Fertil Steril 87(1):101-106

32. Moy V, Jindal S, Lieman H, Buyuk E. Obesity adversely affects serum antimüllerian hormone (AMH) levels in Caucasian women (2015) J Assist Reprod Genet 32(9):1305-1311. doi: https://doi.org/10.1007/s10815-0150538-7.

33. Dólleman M, Verschuren WM, Eijkemans MJ, Dollé ME, Jansen EH, Broekmans FJ, van der Schouw YT (2013) Reproductive and lifestyle determinants of anti-Müllerian hormone in a large population-based study. J Clin Endocrinol Metab 98:2106-2115. https://doi.org/10.1210/jc.2012-3995

34. Mohammad MB, Seghinsara AM (2017) Polycystic ovary syndrome (PCOS), diagnostic criteria, and AMH. Asian Pac J Cancer Prev 18(1):17-21. doi: https://doi.org/10.22034/APJCP.2017.18.1.17.

\section{Publisher's Note}

Springer Nature remains neutral with regard to jurisdictional claims in published maps and institutional affiliations.

\section{Submit your manuscript to a SpringerOpen ${ }^{\circ}$ journal and benefit from:}

- Convenient online submission

- Rigorous peer review

- Open access: articles freely available online

- High visibility within the field

- Retaining the copyright to your article

Submit your next manuscript at $\boldsymbol{\nabla}$ springeropen.com 